\title{
Exploration of Experimental Teaching Mode for Graphic Design
}

\author{
Lei Zhang \\ School of Art and Design \\ Huanghe Science and Technology College \\ Zhengzhou, China \\ e-mail: senlin1573@qq.com
}

\begin{abstract}
With the rapid expansion of higher education's scale, the graphic design major has more and more connection with today's actual social needs and the technical features of this major, but currently there is outstanding obstruction in this connection. In this paper, from the perspective of the experimental teaching mode reform implemented in his teaching unit, the author made an explanation for the shortcomings of the traditional teaching mode of the current graphic design major. Furthermore, in combination with the trial and construction of the experimental teaching mode reform of this major, the author described and analyzed the reform in many aspects, such as teaching ideas, teaching methods, teaching links, talent training objectives, teaching resources reconstruction. Meanwhile, the author also hopes to seek out a new advanced and sustainable way for the graphic design teaching, so as to provide potent reference for new measures of new professional talent training.
\end{abstract}

Keywords-professional education; graphic design; experimental teaching; talents training

\section{INTRODUCTION}

"Teaching has the law but not the changeless method". With the further reform of teaching in higher education, the idea of education aimed at practical and innovative talents is more widely recognized, and the implementation of experimental teaching methods is one of the effective ways to achieve this idea. In general, the experimental teaching mode is to make the education experience involve the thinking process of theory-practice combination through a complete teaching process and achieve the rapid advance of perceptual-to-rational- to-practical knowledge. Furthermore, the goal is to create a practical and innovative talents training mode.

In recent years, the graphic design major has kept up with the times in accordance with the needs of education reform. To make the restructuring of the existing teaching ideas and teaching methods based on the characteristics of the major and increase the energy of "experimental teaching" for the professional education, a teaching mechanism with experimental teaching features should be well-crafted. During the process, the quality of teaching was improved greatly, teachers' teaching level was also upgraded, students began to know not only "what to learn", but also "how to learn".

\section{THE NECESSITY FOR THE IMPLEMENTATION OF EXPERIMENTAL TEACHING}

To strengthen practical ability and innovative spirit in the teaching of graphic design the main content and also one of the important means to deepen the reform in universities currently.

From the social conditions, there are some disjointed and discordant elements between the needs of society and the academic cultivation in universities in recent years. This mainly results from the weak practical ability of these college graduates. Therefore, we should comprehend that it is required for the objective of development to strengthen the experimental teaching and further to improve college students' professional ability and their overall quality.

As far as the self-improvement of graphic design teaching, the traditional teaching mode has not truly reflected the principal status of students in the educational process or the students' experiences, and it cannot achieve the desired teaching effect. On the other hand, the experimental teaching advocates a practical teaching mode of "taking practice as the base, teacher as that direction, student as the educational principal". This experimental teaching mode enables a maneuverable combination of "teaching" and "learning", and takes "learning" as the primary purpose in order to strengthen the principal status of students in the education chain. In the specific implementation, the experimental teaching adopts the teaching as the dominant to mobilize student's enthusiasm, initiative and creativity for practice and knowledge and to finally achieve the rapid selfimprovement of the graphic design major and even the whole art and design education at universities.

From the perspective of the graphic design in our College of Art and Design, the major has obvious "experimental" features, and the desired teaching effect has hardly been achieved by previous methods of teaching and application of many professional aspects of knowledge. Whether from the overall pattern described above or from the specific conditions of graphic design, it has been found that only the exploration and application of experimental teaching modes 
in the graphic design major can meet the development of the whole external environment and can realize the building of a new teaching-orientated platform for social practice, enterprises, market and the future starting point of teaching in graphic design. It will bring far-reaching influence and positive strategic significance for the career planning of students.

\section{THE FIELD EXPANSION OF EXPERIMENTAL TEACHING}

The experimental teaching of graphic design should be based on the theoretical knowledge of the textbook, take students as the principal goal of teaching and be aimed to the solution of practical problems and the improvement of practical operation, especially in regards to ability, thinking, and overall quality, so as to emphasize and consolidate the teaching characteristics of the major. In recent years, we have carried out an exploration of experimental teaching mode for the graphic design major, which has the main features as following:

The application of demonstrative teaching mode in classroom should be addressed. Taking the class of packaging design as an example, in the actual teaching process of the course, we focused on the guidance of students to master the practical operation skills of packaging structure and packaging mechanics of a commodity and further improve their operation and design expansion ability. For example, we let students make a design of package structure for eggs or bulbs with a variety of packaging paper in an unconventional way, and after the completion of their design, all students should make a public demonstration in the class. The demonstration is mainly to test the rationality and security of their design for package structure. This experimental teaching with demonstration not only can break the dull atmosphere in classroom, but also can inspire students' divergent thinking for professional issues.

The development of an open teaching mode should also be addressed. The class teaching of art and design is purposed to fully mobilize the students' subjective creativity and create favorable conditions for their active participation, for which we can greatly attempt and promote the teaching and learning form of "seminar". This teaching mode takes exploration and research as the premise and takes studentteacher interaction and topics discussion as a platform. Teachers carefully select academic topics for the seminar and carefully organized groups for discussion, making students actively participate in the discussion, to finally drive the scientific and positive transition from the traditional knowledge-teaching-oriented mode to the investigative teaching mode. Teachers changed the teaching from a textbook oriented method into a kind of "discussion on design issues", and then guided students to think actively. They combined the fine selection, ideation and creation of design issues with the theory in a complementary way, and they applied professional knowledge to analyze and solve specific design works, in order to achieve a stylized situation and a teaching philosophy that let students go out of the classroom and the campus. Design industry is often regarded as the integration of works and products and it is also the graft between art and technology, therefore the students in art and design major can begin to attempt the proper transition to operate their some professional foundation courses and professional core courses in the society and enterprises at their study stage of Grade 2, so as to obtain effective design experience and professional knowledge.

In order to carry out the cooperation between school and enterprise we should do the following. Graphic design is a learning process involved with the link between artistic conception and effective design performance, and the traditional form of simply using theoretical lectures and class assignments in the past has been increasingly unable to meet the social demands for the major. For example, now some graduates of graphic design have deficient understanding of plate-making and printing process after they enter the job, though they have certain design ideas. Most of the reasons for this phenomenon are directly related to the laggard and deficient teaching ideas of art colleges.

In consideration of current situation, the graphic design department of our Art and Design College keenly realized the developmental trend of the times, so it made cooperation with number of enterprises and design institutions. In the specific cooperation, our school introduced some projects into the professional teaching, to make students be able to learn the major in an actual state. Meanwhile, the teaching and research department organized students to make field investigation in enterprises, by which practicable design materials and information are provided for the design project, to avoid the defects of subjective and impractical design. The teaching and research department often led students to make field study and emulation in the design institutions and the printing shops, where they had exchanges and discussions with designers and printing technicians. In the process, students had a rational and practical understanding of and a contract with the actual situation of design industry and the design process, and in the teaching process the effective complementation can be achieved between the class teaching with full theory but insufficient practice and the enterprises and design institutions with great attention on production but weak in theory. In recent years, the graduation projects of graphic design also expand the space of school-enterprise cooperation. For example, the school appointed students to make media publicity, packaging design and brand planning for the enterprises, and also arranged for them to make internships in the design institution. During this period, the prospective graduates can apply their professional knowledge of four years in the design practice, fully perfect and strengthen their operation ability, and be well prepared for their social work in the future.

Actively participating in academic competitions is also important. The academic competitions of graphic design are mostly involved with the domestic and foreign college students. And these competitions are mostly examined and judged in a professional and pioneering viewpoint. Therefore, the graphic design department often organized students to participate in such competitions, through the tutorship and training, to make students exercise the professional competitions and the severe test for new ideas, so that the experimental teaching and learning can follow the development of the times. Meanwhile, the exchange of 
experiences with other colleges and institutions can also provide reference for the construction of an experimental teaching mode.

\section{PRACTICE AND EXPERIENCE OF EXPERIMENTAL TEACHING MODE}

The art education in universities should take education as the principal part of education-- knowledge and skill should be the educational content, and students should be the educational products. The cultivation of practical talents and creative talents as the purpose and the pursuit of education, by which inheritance of knowledge, application of knowledge and extension of knowledge can be achieved. In the implementation of experimental teaching mode and the development of experimental teaching form for graphic design majors, we get new inspiration, and we also continuously appreciated the achievements in the process and the relative thinking

This will also help to stimulate students' interest in learning. First, the student's age determines they are more interested in practical operation and hands-on performance with respect to the learning of theoretical knowledge. Therefore, to guaranty the quality of the theory teaching, we can apply experimental teaching modes in our class teaching, and inset teaching demonstration, field visits, topic discussions and other experimental teaching content and means in our teaching links such as creating assignments and explanations, will make students driven by a strong initiative and a thirst for knowledge. With this driving force, students' interests will be best developed and make them maintain a good study state over the long term.

It is also important that we help to cultivate students' practical skills relating to the major. The universities cultivate students not only for their textbook knowledge, but also in their professional skills. The experimental teaching of graphic design applies various practical teaching forms and means to let the students of graphic design know that they not only have accomplishment and an appreciation of art and design, but also possess the ability to master and plan professional design tools, design flows and the entire design activities. And the cultivation, training and acquisition of these practical skills all benefit from the support of the platform provided by the experimental teaching mode. Students can better learn and understand their professional knowledge on the "platform" through their personal experience, to finally realize the best combination of theory and practice.

The discipline should also help students to build up their awareness of innovation. In the operation of an experimental teaching mode, students can make their change from a simple knowledge learner into a knowledge applicator, and they will also have many chances to become a knowledge creator. For all of these, higher education and even the graphic design education should keep students on track. In the implementation of experimental teaching, we were fully committed to the creation of a diversified teaching space, to make students be able to get the study information and professional message and professional experience of different aspects, different channels and different forms in their learning process. Abundant professional knowledge will surely expand students' thinking, widen their view and facilitate their new design creativity in the expedient conditions.

Improve the overall standard of teaching and promote the brand building of school and department represents another challenge. Experimental teaching modes emphasize the idea of teaching on the dynamic integration of theory and practice in diversified conditions, its teaching form on pioneering study state, its discussion and exchange of practical operation, and its teaching effect on the availability and development. This is the key reason for experimental teaching mode to improve teaching level. Therefore, the construction of experimental teaching modes made great technical breakthroughs in teaching, all of which are carried around the entire improvement of teaching level. The specific implementation steps of experimental teaching modes benefited the student and enhanced teachers' business level and teaching skill. The integration of overall teaching resources, brought a new look and thriving vitality continuously and also provided a reference or a breakthrough open for the overall teaching reform of colleges or schools.

In summary, education should teach students to learn knowledge, study in a proper way, apply knowledge in proper way, explore knowledge and innovate knowledge. Higher education should emphasizes the cultivation of an innovative spirit and the training of practical abilities, which require various teaching modes to be created scientifically and practically in the reform of professional teaching, so that the educational revolution and educational reform are advanced. The "experimental teaching mode", through the combination of professional education and practical operation of graphic design, becomes the bridge to connect teaching and learning, class and society, and also the only way to enhance the school-running level of art colleges. Art colleges and universities, especially the department of graphic design should actively boost the reform guidelines and be tasked with the implementation of experimental teaching mode according to the teaching idea of grafting of technology and the integrating of production and learning, to strive for achievement of teaching reform purpose of "profession + practice + project", and finally form the new teaching mode favorable for cultivation of art design talents.

\section{REFERENCES}

[1] Ma Minghua, Tu Zhengming. Discussion on Humanistic Quality Education in Colleges and Universities [M]. Guangzhou: South China University of Technology Press, 2010.

[2] Wu Zhaofang, Chen Guangshu.Students' Quality Development Training [M] Shanghai: Tongji University Press, 2010.

[3] Qiao Jianzhong Integration of Cognition and Emotion: New Exploration on Teaching Mode [M]. Hefei: Anhui People's Publishing House, 2010.

[4] Yu Wensen, Hong Ming, Zhang Rong. Effective Teaching Theories and Models [M] Fuzhou: Fujian Education Press, 2011.

[5] Mao Weixia, Li Xiaoli. Happy Thinking Teaching Mode [M]. Nanjing: Jiangsu Fine Arts Publishing House, 2011. 
[6] Chen Hongling, Yu Lifen. Theory and Practice on Talents Training Mode after College Enrollment Expansion [M]. Beijing: Beijing Normal University Press, 2011.

[7] Xia Zhonglei. Quantitative Study on the relationship between college students training cost and school-running scale [M] Beijing: Intellectual Property Publishing House, 2011. 